\title{
Serum Metabolic Profile Based Assessment of Nutritional Status of Temperate Crossbred, Stall-fed, Lactating Dairy Cows: A Case Study of a Medium Scale Mid-country Cattle Farm
}

\author{
H.M.G.P. Herath, K.K.T.N. Ranaweera, \\ W.M.P.B. Weerasinghe ${ }^{1}$ and M.B.P. K. Mahipala ${ }^{2 *}$ \\ Postgraduate Institute of Agriculture \\ University of Peradeniya \\ Sri Lanka
}

\begin{abstract}
Nutritional status of temperate crossbred dairy cows at post-partum transition, early-lactation and mid-lactation stages of a medium-scale farm in mid-country was assessed through serum metabolic profile. Body weight, body condition score and milk production of cows were recorded. Cows were bled and serum was analyzed for nonesterified fatty acids (NEFA), beta-hydroxybutyrate (BHBA), urea, albumin, calcium and phosphorous contents. Levels of metabolites were compared with respective critical limits of the reference ranges proposed to assess the state of energy balance. Weight and body condition score of cows at different physiological stages were compared. Nutrient and energy content of the forage and concentrate mixed ration of the cows were analyzed. Requirement and intake of crude protein and metabolizable energy were computed. Serum NEFA content of cows at post-partum transition, early-lactation and mid-lactation, nonpregnant stages exceeded the upper critical limit of the reference range, indicating that temperate crossbred cows managed in the mid-country suffer from negative energy balance. The low level of serum BHBA recorded at all stages of lactating cows suggested that they have adapted for the state of negative energy balance. Serum urea content of the lactating cows exceeded the upper critical limit of the reference range due to the feeding of energy protein imbalanced ration. Adopting an energy protein balanced feeding programme is warranted to optimize the productivity while minimizing incidence of metabolic disorders in temperate crossbred dairy cows.
\end{abstract}

Keywords: BHBA, NEFA, negative energy balance, urea

\section{INTRODUCTION}

Mild climate, abundance of water in most areas and availability of natural and improved forage provide suitable environment for dairying in the mid-country region (Subasinghe and Abeygunawardena, 2013). Dairy cattle herd of the region composed of purebred (25\%) and crossbred (75\%) of temperate cattle (Jersey, Ayrshire, Friesian) (Ibrahim et al., 1999). In spite of great potential, reported milk productivity of dairy cows ranged only between 4 to 7.7 L/cow/day (Alexander et al., 1997; Ibrahim et al., 1999; Mahipala and Fernando, 2005; Serasinghe, 2008). Lack of roughages and high price of concentrates were identified as the

\footnotetext{
1 Veterinary Research Institute, Gannoruwa, Peradeniya, Sri Lanka

2 Department of Animal Science, Faculty of Agriculture, University of Peradeniya, Sri Lanka

* Corresponding author: pmahi@pdn.ac.lk
} 
major constraints for dairying in the area (Mahipala and Fernando, 2005; Sanjeewa, 2008). As such, it is important to develop feeding strategy to improve productivity of dairy cattle in the mid-country. However, assessment of nutritional status of cattle is required prior to such developments.

Modern biochemical methods could provide tools to precise identification of nutritional status of animals. As reported by Ndlovu et al. (2007), blood metabolites are used to indicate the level of nutrient metabolism. Further, the concentration of blood metabolites represents the balance of nutrient supply and utilization, indicating nutritional status of animals at the moment of sampling (Cronjé and Pambu-Gollah, 1996). Therefore, blood metabolic profile is widely used for identification of nutritional status, dietary causes for diseases, milk production and for assessing the reproductive performances in dairy cattle (Lee et al., 1978). Plasma non-esterified fatty acids (NEFA) and beta-hydroxybutyrate (BHBA) levels are indicators of body fat mobilization and negative energy balance (NEB) of dairy cattle (Grummer, 1993). Serum urea, albumin and minerals are reliable indicators for routine identification of nutritional and metabolic status of cattle (Ndlovu et al., 2007). Changes in body weight, body condition score together with blood or milk urea nitrogen level is useful to assess the protein energy status of dairy cattle (Andrew, 1998). Therefore, the present study was conducted to assess the nutritional status of lactating dairy cows of a medium scale farm in mid-country.

\section{MATERIALS AND METHODS}

\section{Selection of cows and data collection}

The study was carried out at a medium-scale dairy cattle farm in mid-country, Sri Lanka (Sri Lak Farm, Nawalapitiya). Temperate crossbred dairy cows at transition (3 weeks postpartum, $n=15)$, early-lactation (4 - 15 weeks post-partum, $n=15)$ and mid-lactation (16 - 25 weeks post-partum) pregnant $(n=15)$ and non-pregnant $(n=15)$ stages were assessed. The cows were fed three (3) times a day with forage-concentrate mixed ration (Table 3) and maintained in tie-stall system. Water was available ad-libitum for each cow. Milk production and body condition score (1-5 scale; Ferguson et al., 1994) were recorded on the day of blood sample collection. The cows were diagnosed for pregnancy by rectal palpation technique. The forage concentrate mixed ration of the cows was sampled and analyzed for dry matter, crude protein (CP) and metabolizable energy (ME) contents. Nutrient requirement for cows (380 $\mathrm{kg}$ of body weight with $10.5 \mathrm{~L} / \mathrm{d}$ milk production) and respective intake were computed.

\section{Determination of serum metabolic profile}

After morning milk each cow was bled through jugular or coccygeal vein into blood collecting tubes without EDTA. Blood samples were allowed to clot at room temperature for $3 \mathrm{~h}$ before centrifugation at $2000 \mathrm{X} \mathrm{g}$ for 10 minutes. Harvested serum samples were stored at $-20{ }^{\circ} \mathrm{C}$ until analysis of the serum metabolic profile. The content of serum non-esterified fatty acids (NEFA), beta-hydroxybutyrate (BHBA), urea, albumin, calcium and phosphorous were determined using Randox serum test kits (Randox Laboratory Limited, United Kingdom) and auto analyzer (3000 Evolution ${ }^{\circledR}$ auto analyzer, Biochemical System International, Arezzo, Italy). 


\section{Data analyses}

The upper and lower critical limits (i.e. reference ranges) of serum metabolites of temperate crossbred dairy cows for identification of state of negative energy balance have been presented in the Table 1. Statistics of metabolic profile of cows at different physiological stages were compared with respective critical limits of the reference ranges. Analysis of variance (ANOVA) was performed to compare body weight and BCS of the cows at different physiological stages using the version 9.2 of SAS software (SAS Institute Inc., 2003). Additionally, the BCS were compared with respective recommended BCS of 5-point scale (Klopcic et al., 2011).

Table 1. Reference range of serum metabolites of temperate crossbred dairy cows for identification of state of negative energy balance

\begin{tabular}{lccl}
\hline Metabolite & \multicolumn{2}{c}{ Critical limits } & \multicolumn{1}{c}{ Citation } \\
\hline & Upper limit & Lower limit & \\
\hline NEFA $(\mathrm{mmol} / \mathrm{L})$ & 0.01 & 0.52 & Penn State Extension, 2017. \\
BHBA (mmol/L) & 0.30 & 1.50 & Penn State Extension, 2017. \\
Albumin $(\mathrm{g} / \mathrm{dL})$ & 2.80 & 3.90 & Kahn and Line, 2011. \\
Urea $(\mathrm{mg} / \mathrm{dL})$ & 5.00 & 27.00 & Lager and Jordan, 2002. \\
$\mathrm{Ca}(\mathrm{mg} / \mathrm{L})$ & 7.00 & 11.00 & Puls, 1989. \\
$\mathrm{P}(\mathrm{mg} / \mathrm{L})$ & 4.30 & 8.00 & Lager and Jordan, 2002. \\
\hline
\end{tabular}

\section{RESULTS AND DISCUSSION}

The serum NEFA content recorded in temperate crossbred cows examined in the present study at post-partum transition, early-lactation and mid-lactation, non-pregnant stages exceeded the upper critical limit of the reference range (Table 1 and Figure 1). However, the serum NEFA content of the pregnant cows at mid-lactation was lower than the upper critical limit of the reference range. Walters et al., (2002) reported relatively low serum NEFA content in cows at mid-lactation owing to the positive energy balance and replace mobilized tissue reserves. Temperate cows fed adequately and managed under tropical climate, conceive around 12 weeks of post-partum (Ageeb and Hayes, 2000). However, in the present study none of the temperate crossbred cows was diagnosed to be pregnant until 15 week of the post-partum stage and only $32 \%$ cows at mid-lactation were diagnosed to be pregnant. State of NEB in dairy cattle delayed post-partum estrus (Spicer et al., 1990) and delay conception (Butler, 2003) resulting higher open days (Reist et al., 2003) and longer calving interval (Butler, 2003). Therefore, the results confirmed that transition, early-lactating and mid-lactating and non-pregnant temperate crossbred cows under present management in midcountry are at the state of NEB. Further, the results confirmed that delayed conception in temperate crossbred dairy cattle in the mid-country is due to state of NEB.

Drackley (1999) reported that NEFA concentration peaks around parturition and maintained at a high level during two weeks of post-partum stage in cattle. Yet, the serum NEFA content of the temperate crossbred dairy cows of present study reached the peak a little later, during the early-lactation stage (4-15 weeks post-partum) and declined towards the mid-lactation stage (Figure 1). Serum NEFA resulted from metabolization of body fat reserves to meet greater energy demand for increasing lactation (Overton and Waldron 2004). Temperate cows managed under tropical conditions reach the peak milk production around 8 weeks 
post-partum (Patel, 2015) and thus the NEFA peak observed during the same stage (4-15 weeks post-partum) is realized. Early lactating cows of the present study recorded a significantly low $(P<0.05)$ BCS. According to Klopcic (2011), the BCS of an average fresh cows (0-4 weeks post-partum) should not have fallen below 3.0 to 2.5 of 5-point scale. Further, they recommended BCS of 2.5 to 3.0 and 3.0 for early-lactating (4-16 weeks postpartum) and mid-lactating dairy cows, respectively. Thus, the poor BCS recorded by early and mid-lactating cows of the present study (Table 2) is an indication of the use of body reserves for increased milk lactation. Therefore, the highest NEFA content recorded in cows of present study at early-lactation could be due to metabolization of body fat to meet high energy demand for peak milk production. Present findings also agree with Adewuyi et al. (2005), who reported that serum NEFA concentration had a decreasing tendency as the lactation progressed.

Table 2. Body weight and body condition score (BCS) of temperate crossbred dairy cows

\begin{tabular}{lll}
\hline Stage of lactation/ pregnancy & Body weight $(\mathbf{k g})^{\dagger *}$ & BCS $^{\dagger *}$ \\
\hline $\begin{array}{l}\text { Post-partum transition } \\
\text { Early-lactation }\end{array}$ & $356.50 \pm 13.29^{\mathrm{b}}$ & $2.50 \pm 0.18^{\mathrm{a}}$ \\
Mid-lactation & $360.18 \pm 14.14^{\mathrm{b}}$ & $2.00 \pm 0.12^{\mathrm{b}}$ \\
$\quad \quad \quad$ Non-pregnant & $395.59 \pm 10.54^{\mathrm{a}}$ & $2.23 \pm 0.16^{\mathrm{a}}$ \\
$\quad-\quad$ Pregnant & $401.88 \pm 19.66^{\mathrm{a}}$ & $2.41 \pm 0.26^{\mathrm{a}}$
\end{tabular}

', Mean \pm SE.

*, Means followed by different superscripts within a column are significantly different $(P<0.05)$.

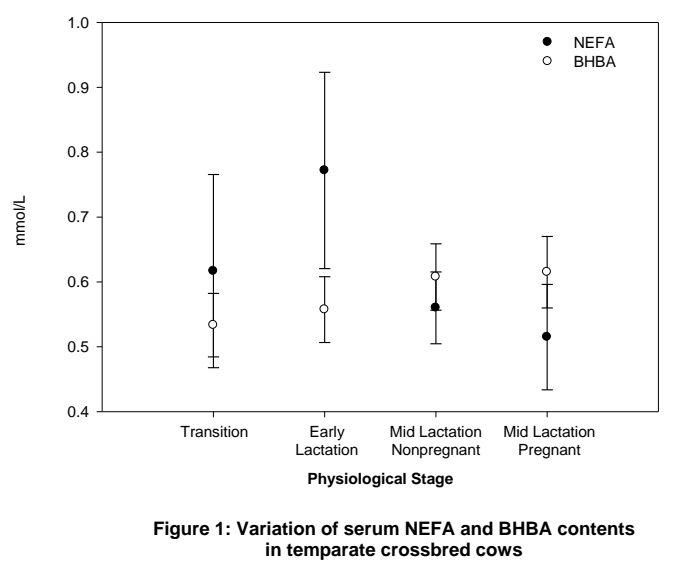

In spite of high serum NEFA content, the serum BHBA content recorded in temperate crossbred cows in the present study were within the upper and lower critical limits of the reference range (Table 1 and Figure 1). Level of serum BHBA is also an indicator of energy balance which evaluates the success of adaptation to negative energy balance in dairy cows (Giesecke, 1987). Serum NEFA converted to acetyl CoA are effectively utilized for energy production in tricarboxylic acid cycle by complete oxidation resulting low level of serum BHBA (Grummer, 2008). The animals at the state of NEB, partially oxidize NEFA and 
produce more ketone bodies such as BHBA and acetoacetates (McDonald et al., 2011). Extended walking activity also caused to decrease the serum NEFA content (Adewuyi et al., 2006). The temperate crossbred cows investigated in the present study were managed in tiestall system and thus, obviously have had low muscle activity. Therefore, partial oxidation of NEFA which produces excessive amounts of BHBA may have not been encouraged and thus, low level of serum BHBA may have been resulted, despite they were at the state of NEB. Thus, it can also be postulated that temperate crossbred cows in mid-country have successfully adapted for state of NEB.

It is important to record that the cows supplemented with recommended level of mineral premixture and thus both serum calcium and phosphorous levels were found to be ranged within respective limits of the reference range (Table 1 and Figure 2). The serum urea content of transition, early and mid-lactating dairy cows in the present study were beyond the upper limit of the reference range (Table 1 and Figure 3). Surplus nitrogen supplements also convert to ammonia, due to ruminal fermentation resulting high rumen ammonia concentration (Abdoun et al., 2006).

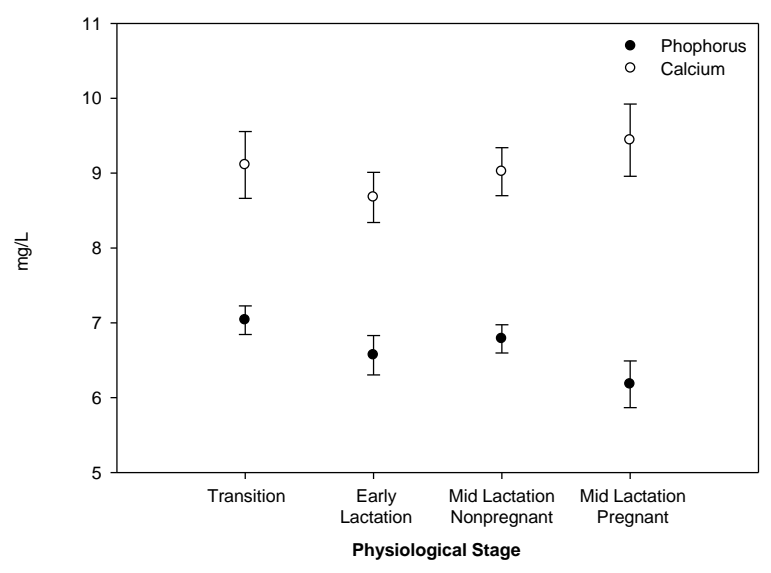

Figure 2: Variation of serum Phophorus and Calcium contents in temparate crossbred cows

It is well described that the excess ammonia for microbial protein synthesis enters to the liver and converts to urea and subsequently excretes with urine. Further, some urea diffuses back to rumen, to saliva and to milk in lactating cows. The occurrence of blood urea nitrogen higher than 19-20 mg/dL may result from high dietary protein intake (Butler et al., 1996). Butler (2000) reported that high serum urea content results from high dietary protein intake for a long period or lack of dietary energy in dairy cow rations. Despite the recorded high serum urea content, the serum albumin content recorded in temperate crossbred cows of the present study were within the critical limits of the reference range (Table 1 and Figure 4). Although, cows in the present study have received adequate amount of dietary proteins the ME intake was far below compared to the requirement (Table 3). Therefore, the results proved that post-partum transition, early-lactating and mid-lactating temperate crossbred dairy cows fed with energy protein imbalanced ration (low energy) under current feeding practices in mid-country suffer from NEB due to inadequate energy intake. 
Herath et al.

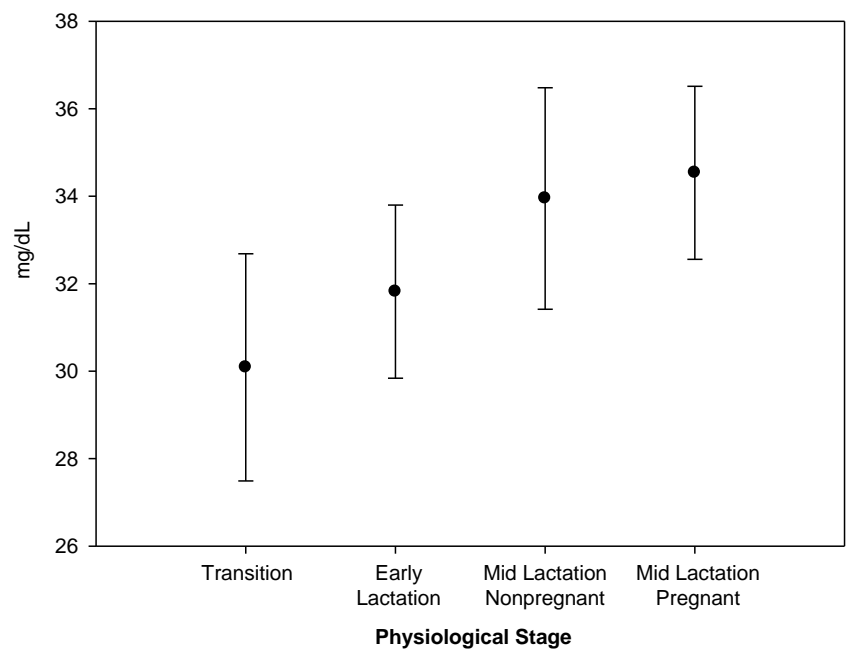

Figure 3: Variation of serum Urea content in temparate crossbred cows

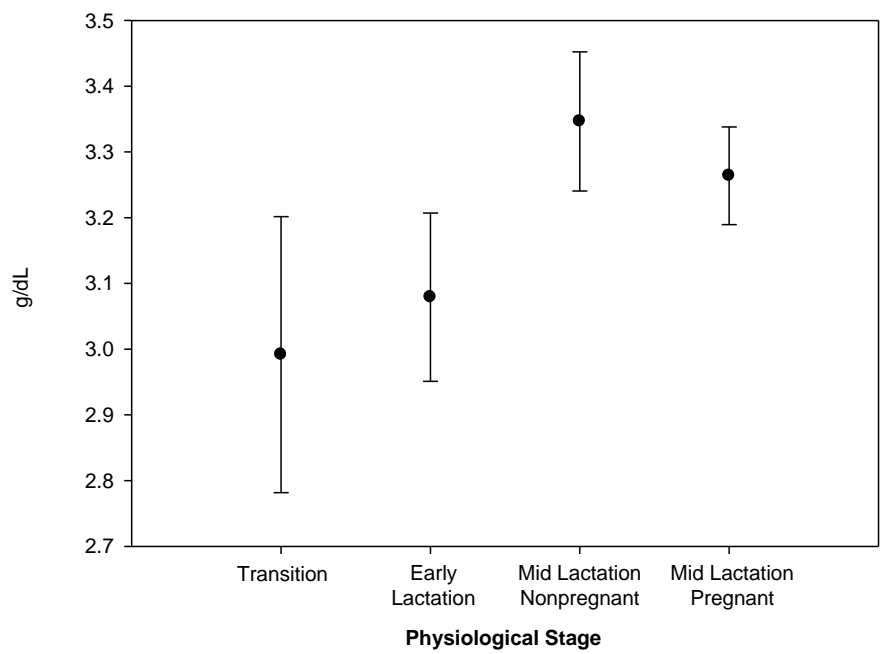

Figure 4: Variation of serum Albumin content in temparate crossbred cows 
Table 3. Ration composition, nutritive value, nutrient requirement and nutrient intake of temperate crossbred dairy cows

\begin{tabular}{ll}
\hline Parameter & Observation \\
\hline Ration composition (g/kg Dry matter) & \\
- Grass & 435.52 \\
- Coconut Poonac & 208.90 \\
- Dhal husk & 120.71 \\
- Rice polish & 210.04 \\
- Beer pulp & 11.51 \\
- Mineral mixture & 6.64 \\
- Salt & 6.64 \\
& \\
Nutritive value of mixed ration & 35.33 \\
- DM (\%) & 13.39 \\
- CP (\%) & 8.33 \\
- ME (MJ/kg DM) & \\
Nutrient intake from mixed ration & 1.23 \\
- CP (kg/cow/day) & 76.58 \\
- ME (MJ/cow/day) & \\
Nutrient requirement (NRC, 2001)* & 1.20 \\
- CP (kg/cow/day) & 94.43 \\
- ME (MJ/cow/day) &
\end{tabular}

* $380 \mathrm{~kg}$ Body weight, $10.5 \mathrm{~L} / \mathrm{d}$ Milk production

Ospina et al., (2010) proposed a critical serum NEFA concentration of $0.57 \mathrm{mmol} / \mathrm{L}$ to predict metabolic disorders such as displaced abomasum, clinical ketosis, metritis and retained placenta, Thus, greater incidence of metabolic disorders could be expected in transition and early-lactating temperate crossbred dairy cows under the current management in the mid-country region.

\section{CONCLUSIONS}

The present serum metabolic profile assessment concludes that transition, early-lactating and mid-lactating non-pregnant temperate crossbred cows suffer from negative energy balance under the present management in mid-country region. This energy state delays the conception of dairy cows in the region. Further, the cows at transition and early-lactation may at a risk of metabolic disorders. Adaptation of appropriate feeding strategy particularly with the focus to overcome energy protein imbalance is warrant to optimize the productivity of temperate crossbred lactating dairy cows in mid-country.

\section{ACKNOWLEDGEMENTS}

This work was funded by the National Research Council, Sri Lanka (Grant No. NRC TO 1410). Authors acknowledge assistance of Prof. Basil Alexandra, Dr. K. Nizananthan and Dr. Devinda Wickramasinghe for diagnose pregnancy of the cows. Mr. Buddhika Gunathilake, 
Managing Director of Sri Lak Farm is acknowledged for facilitating to conduct the research at the farm.

\section{REFERENCES}

Abdoun, K., Stumpff, F. and Martens, H. (2006). Ammonia and urea transport across the rumen epithelium: A review. Anim. Health Res. Rev. 7, 43-59.

Adewuyi, A.A., Gruys, E. and Van Eerdenburg, F.J.C.M. (2005). Non esterified fatty acids (NEFA) in dairy cattle: A Review. Vet. Q. 27, 117-126.

Adewuyi, A.A., Roelofs, J.B., Gruys, E., Toussaint, M.J.M. and Van Erdenburg, F.J.C.M. (2006). Relationship of plasma nonesterified fatty acids and walking activity in postpartum dairy cows. J. Dairy Sci. 89, 2977-2979.

Ageeb, A.G. and Hayes, J.F. (2000). Reproductive responses of Holstein-Friesian cattle to the climatic conditions of Central Sudan. Trop. Anim. Health Prod. 32, 233-243.

Alexander, P.A.B.D., Abeygunawardena, H., Perera, B.M.A.O. and Abeygunawardena, I.S. (1997). Current status and factors affecting the success of artificial insemination in smallholder farms in the mid country wet zone of Sri Lanka. Trop. Agric. Res. 9, 204-216.

Andrew, C.H. (1998). Use of BUN and MUN as guides for protein and energy supplementation in cattle. Revtsfa Corpotca. 2, 44-48.

Butler, W.R. (2000). Nutritional interactions with reproductive performance in dairy cattle. Anim. Reprod. Sci. 60, 449-457.

Butler, W.R. (2003). Energy balance relationships with follicular development, ovulation and fertility in postpartum dairy cows. Livest. Prod. Sci. 83, 211-218.

Butler, W.R. Calaman, J.J. and Beam, S.W. (1996). Plasma and milk urea nitrogen in relation to pregnancy rate in lactating dairy cattle. J. Anim. Sci. 74, 858-865.

Cronje, P. B. and Pambu-Gollah, R. (1996). The use of blood profiles as animal response indicators. Bull. Grassland Soc. S. Africa. 7, 28-35.

Drackley, J.K. (1999). Biology of dairy cows during the transition period: the final frontier? J. Dairy Sci. 82, 2259-2273.

Ferguson, J.D., Galligan, D.T. and Thomsen, N. (1994). Principal descriptors of body condition score in Holstein cows. J. Dairy Sci. 77, 2695-2703.

Giesecke, D. (1987). Lipid mobilization and insulin function in cows with high milk yield. Paul Parey, Ham-burg, Berlin, Germany.

Grummer, R.R. (2008). Nutritional and management strategies for the prevention of fatty liver in dairy cattle. Vet. J. 176, 10-20. 
Grummer, R.R. (1993). Etiology of lipid-related metabolic disorders in periparturient dairy cows. J. Dairy Sci. 76, 3882-3896.

Ibrahim, M.N.M., Staal, S.J., Daniel, S.L.A. and Thorpe, W. (1999). Appraisal of the Sri Lanka Dairy Sector: Synthetic Report. 1, 9-10.

Klopcic, M., Hamoen, A. and Bewley, J. (2011). Body condition scoring of dairy cows. Department of Animal Science, Faculty of Biotechnical, University of Ljubljana, Groblje, Domzale. pp.1-42.

Kahn, C.M. and Line, S. (2011). Merck Veterinary Manual. $10^{\text {th }}$ Ed, Merck and Co., Whitehouse Station, U.S.A.

Lager, K. and Jordan, E. (2012). The metabolic profile for the modern transition dairy cow. Mid-South Ruminant Nutrition Conference, Grapevine, Texas. pp. 9-16.

Lee, J., Twardock, R., Bubar, R.H., Hall, J.E. and Davis, C.L. (1978). Blood metabolic profiles: their use and relation to nutritional status of dairy cows. J. Dairy Sci. 61, 1652-1670.

Mahipala, M.B.P. and Fernando P.V.C. (2005). Viability of integrated cattle farming in midcountry, intermediate zone, Sri Lanka. Proceedings of integrating livestock crop system to meet the challenges of globalization, AHAT/BSAS International Conference, Thailand. 2, 66.

McDonald, P., Edwards, R., Greenhalgh, J.F.D., Morgan, C., Sinclair, L. and Wilkinson, R.G. (2011). Animal Nutrition. $7^{\text {th }}$ Ed. Pearson, London.

National Research Council (2001). Nutrient requirements of dairy cattle: 2001. National Academies Press, Washington, DC.

Ndlovu, T., Chimonyo, M., Okoh, A.I., Muchenje, V., Dzama, K. and Raats, J.G. (2007). Assessing the nutritional status of beef cattle: current practices and future prospects. Afr. J. Biotechnol. 6, 2727-2734.

Ospina, P.A., Nydam, D.V., Stokol, T. and Overton, T.R. (2010). Evaluation of nonesterified fatty acids and $\beta$-hydroxybutyrate in transition dairy cattle in the northeastern United States: Critical thresholds for prediction of clinical diseases. J. Dairy Sci. 93, 546-554.

Overton, T.R. and Waldron, M.R. (2004). Nutritional management of transition dairy cows: strategies to optimize metabolic health. J. Dairy Sci. 87, 105-119.

Patel, A.C. (2015). Study on persistency of milk production in Holstein Friesian cattle on an organized farm. Int. J. Appl. Pure Sci. Agric. 1, 37-38.

Penn State Extension (2017). Metabolic profiling of transition cows : can we predict impending problems [on line]. [Accessed on 04.01.2017]. Available at https://extension.psu.edu/animals-and-livestock

Puls, R. (1989). Mineral levels in animal health: Diagnostic data. pp. 5-152. In: Mahaffey K.R. (Ed.). Minerals in Animal Nutrition. Sherpa Int., Clearbrook, BC, Canada. 
Reist, M., Erdin, D.K., Von Euw, D., Tschumperlin, K.M., Leuenberger, H., Hammon, H.M., Morel, C., Philipona, C., Zbinden, Y., Kunzi, N. and Blum, J.W. (2003). Postpartum reproductive function: association with energy, metabolic and endocrine status in high yielding dairy cows. Theriogenology. 59, 1707-1723.

Sanjeewa, T.A.B.D. (2008). Status and profitability of dairy cattle farming in mid country intermediate zone of Sri Lanka. In; Proceedings of second annual research session, Sri Lanka Agriculture Economics Association, University of Peradeniya. pp. 11.

SAS Institute Inc. (2003), Cary, North Carolina, U.S.A.

Serasinghe, T. (2008). Feeding dairy animals for higher milk yield. Economic Review. pp. 33-37.

Spicer, L.J., Tucker, W.B. and Adams, G.D. (1990). Insuline - like growth factor-I in dairy cows: relationships among energy balance, body condition, ovarian activity, and estrus behaviour. J. Dairy Sci. 73, 929-937.

Subasinghe, D.H.A. and Abeygunawardena, H. (2013). Dairy industry in Sri Lanka, part III, S.L. Vet. J. 60, 25-34.

Walters, A.H., Pryor, A.W., Bailey, T.L., Pearson, R.E. and Gwazdauskas, F.C. (2002). Milk yield, energy balance, hormone, follicular and oocyte measures in early and mid-lactation Holstein cows. Theriogenology. 57, 949-961. 